$\underline{\text { Article }}$

\title{
Essential Oil in the Taxonomy of Ocimum selloi Benth ${ }^{\#}$
}

\author{
Ernane R. Martins ${ }^{a}$, Vicente W. D. Casali ${ }^{* a}$, Luiz C. A. Barbosa* ${ }^{* b}$, \\ and Fernando Carazzac \\ ${ }^{a}$ Departamento de Fitotecnia, Universidade Federal de Viçosa, \\ 36571-000 Viçosa - MG, Brazil \\ ${ }^{b}$ Laboratório de Análise e Síntese de Agroquímicos (LASA) Departamento de Química, \\ Universidade Federal de Viçosa, 36571-000 Viçosa - MG, Brazil \\ ${ }^{c}$ Departamento de Química, ICEx, Universidade Federal de Minas Gerais,
} 31270-901 Belo Horizonte - MG, Brazil

Received: December 9 1995; August 12, 1996

\begin{abstract}
A composição química do óleo essencial das folhas e flores de dois acessos de Ocimum selloi Benth., cultivados na Universidade Federal de Viçosa foi analisada. Para o acesso A o componente principal foi identificado como estragol, o qual representa $94,95 \%$ e $92,54 \%$ do óleo das folhas e das flores, respectivamente. O óleo obtido das folhas e flores do acesso B é constituído de $65,49 \%$ e $66,18 \%$ de metil eugenol, respectivamente. Para ambos os acessos, diversos constituintes químicos, presentes em quantidades menores, foram identificados. As diferenças fenotípicas e químicas observadas entre os dois acessos estudados indicam a existência de duas variedades quimicamente distintas de Ocimum selloi Benth.

Chemical composition analysis of the essential oil from the leaves and flowers of two accessions of Ocimum selloi Benth, cultivated at the Federal University of Viçosa was carried out. For accession A the major component was identified as estragole and represented $94,95 \%$ and $92,54 \%$ of the oil from the leaves and flowers respectively. For accession B, the oil from the leaves and flowers was constituted by $65,49 \%$ and $66,18 \%$ of methyleugenol, respectively. For both accessions several minor constituents were also identified. The phenotypic and chemical differences observed between these two accessions suggest the existence of two chemicaly distinct varieties for Ocimum selloi Benth.
\end{abstract}

Keywords: Ocimum selloi, estragole, methyleugenol

\section{Introduction}

The genus Ocimum (Labiatae) comprises 160 species and is found throughout the tropical and sub-tropical regions of the world $^{1}$. The larger genetic diversity of this genus is found in Brazil $^{1}$. Several species of this genus has commercial utility as a source of essential oil for the pharmaceutic, food, flavour and perfumary industries ${ }^{2}$.

The specie Ocimum selloi Benth known as "alfavaquinha", "anis" and "elixir-paregorico", is originated from South America, and is used in the traditional medicine as antiinflammatory, analgesic and antiespasmodic ${ }^{3}$.

\# Taken from the MSc dissertation presented by E.R.M. at the Federal University of Viçosa on February 1996.
In the germplasm collection kept at the Federal University of Viçosa, accessions of this specie were found to have different morphological characteristics. The accession having more vigorous plants, with pink corollas and leaves with an anis-like odour was called "A". The accession formed by smaller plants, with darker corollas, reddish calyx and leaves without anis-like odour was called "B". Thus a chemical analysis of the essential oil of these two accessions was carried out in order to see if the phenotypic variability observed was also present at molecular level. Information about the chemical composition of the oil could then be useful in the classification of these plants. 


\section{Material and Methods}

\section{Plant material}

Seeds of Ocimum selloi, accessions A and B, from the germplasm collection of the "Grupo Entre-Folhas-Viçosa (MG)", were cultivated at the Federal University of Viçosa, beginning November 1994 and harvested while in full bloom in April 1995. The aerial parts were collected and the leaves and flowers were separated.

\section{Essential oil extraction}

Steam distillation was carried out by passing steam in a 2 $\mathrm{L}$ round-bottoned flask containing the fresh plant material (100 $\mathrm{g}$ of leaves or $80 \mathrm{~g}$ of flowers). A total of $850 \mathrm{~mL}$ of distil late was collected, and the oil was extracted with diethyl ether $(3 \times 80 \mathrm{~mL})$. The combined organic extract was dried over $\mathrm{MgSO}_{4}$ and concentrated under reduced pressure in a rotary evaporator at $30{ }^{\circ} \mathrm{C}$, and the essential oil obtained was weighted. The extractions were carried out in triplicates, and for each extraction the material (leaves and flowers) were ob tained from one single specimen.

\section{Essential oil analysis}

The major constituent of the essential oil from each plant group was purified by column chromatography on silica gel, using hexane or hexane:diethyl ether $(8: 1)$ as a solvent for groups A and B respectively. The compounds isolated were identified by means of their MS, IR and ${ }^{1} \mathrm{H}-\mathrm{NMR}$ data.

IR spectra were recorded with a Perkin Elmer 599B dou ble beam grating spectrophotometer; ${ }^{1} \mathrm{H}-\mathrm{NMR}$ spectra were recorded with a Bruker WH300 (300 MHz) in strument, using tetramethylsilane as internal standard.

Data for estragole

IR (thin film) $\mathrm{v}^{-} / \mathrm{cm}^{-1}: 3085,3010,2990,2950,2900,2830$, 1635, 1608, 1580 and 1510; 1H-NMR (300 MHz, CDCl 3) $\delta$ : 3.35 (d, J=6.5 Hz, $\mathrm{CH}_{2}$ ), 3.78 (s, OCH 3), 5.00-5.15 (m, =CH 2), 5.85-6.15 (m , =CH), $6.82(\mathrm{~d}, \mathrm{~J}=9.0 \mathrm{~Hz}), \mathrm{Ha} / \mathrm{Ha}), 7.10$ (d, J= $\left.9.0 \mathrm{~Hz}, \mathrm{Hb} / \mathrm{Hb}^{\prime}\right) ; \mathrm{MS} \mathrm{m} / \mathrm{z}(\%): 148\left(\mathrm{M}^{+}, 100\right), 133$ (22), 121 (35), 117 (41), 105 (23), 91 (32) and 77 (38).

\section{Data for methyleugenol}

IR (thin film) $\bar{v} / \mathrm{cm}^{-1}: 3060,2990,2930,2820,1635,1590$ and 1510; $1 \mathrm{H}-\mathrm{NMR}(300 \mathrm{MHz}, \mathrm{CDCl}$ ) $\delta: 3.35(\mathrm{~d}, \mathrm{~J}=6.5 \mathrm{~Hz}$, $\left.\mathrm{CH}_{2}\right), 3.85$ and 3.87 (2s, 2x OCH 3), 5.02-5.15 (m, =CH 2), 5.85-6.07 $(\mathrm{m},=\mathrm{CH}), 6.70-6.85(\mathrm{~m}, 3 \mathrm{H}$ ar o matic ring); $\mathrm{MS} \mathrm{m} / \mathrm{z}$ (\%): $178\left(\mathrm{M}^{+}, 100\right), 163$ (35), 147 (33), 135 (10), 107 (30), 91 (28) and 77 (14).

Minor constituents were identified by combined GC-MS analysis. These were performed by a model 5890 A GC system with mass-selective detector Model 5970 (Hewlett-Packard). GC conditions were: direct injection of $1.0 \mu \mathrm{L}$ sample diluted 10:1 with $\mathrm{CHCl}_{3}$; fused sil ica col umn HP-1(30 m x $0.25 \mathrm{~mm}$ x
$0.33 \mu \mathrm{m})$; helium as a carrier gas $(1.0 \mathrm{~mL} / \mathrm{min})$; oven program 80 ${ }^{\circ} \mathrm{C}\left(5^{\circ} \mathrm{C} / \mathrm{min}, 1 \mathrm{~min}\right.$ hold $)$ to $250^{\circ} \mathrm{C}$, injector and detector temperature of $150{ }^{\circ} \mathrm{C}$ and $225{ }^{\circ} \mathrm{C}$ respectively. All spectra were recorded in the electron impact ionization mode at $70 \mathrm{ev}$. The comparisons of the acquired spectra were made with those found in a Wiley library by an integrated program.

A quantitative analysis of the major chemical constituents of the essential oil was carried out using a Shimadzu GC-14A instrument, equipped with a FID detector, a Carbowax 20M capillary column of $30 \mathrm{~m}$, i.d. $0.25 \mathrm{~mm}$ and the following temperature program: $60{ }^{\circ} \mathrm{C}(1 \mathrm{~min})$ rising to $160{ }^{\circ} \mathrm{C}$ at the rate of $5{ }^{\circ} \mathrm{C}$; injector and detector temperatures of $150^{\circ} \mathrm{C}$ and $220^{\circ} \mathrm{C}$ respectively. Carrier gas used was hydrogen at $1.0 \mathrm{~mL} / \mathrm{min}$. Estragole and methyleugenol, purified previously, were used as standards, and the analysis were carried out in triplicates.

\section{Results and Discussion}

The essential oil content in the fresh leaves and flowers of accession A were $0.311 \pm 0.043 \%$ (average \pm standard deviation) and $0.474 \pm 0.036 \%$, respectively, and for accession B $0.210 \pm 0.022 \%$ and $0.398 \pm 0.015 \%$.

Chromatograms of the essential oils from the leaves and flowers of both accessions of Ocimum selloi are shown in Figs. 1 and 2. The compounds identified are listed in Table 1 , and the relative area $(\%)$ of each compound is also presented.

The major compound found in the oil from the leaves and flowers of accession A was identified by GC/MS as estragole (Fig. 3) This oil was submitted to fractioning in a
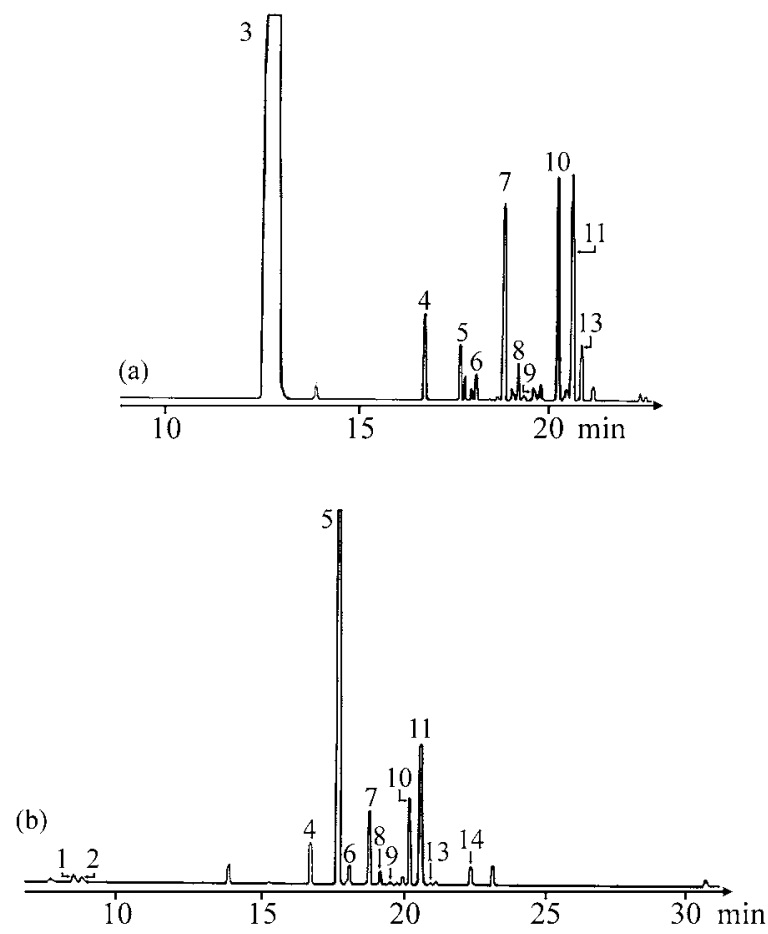

Figure 1. Chromatogram of the essential oil from the leaves of Ocimum selloi Benth.: (a) accession A and (b) accession B. 


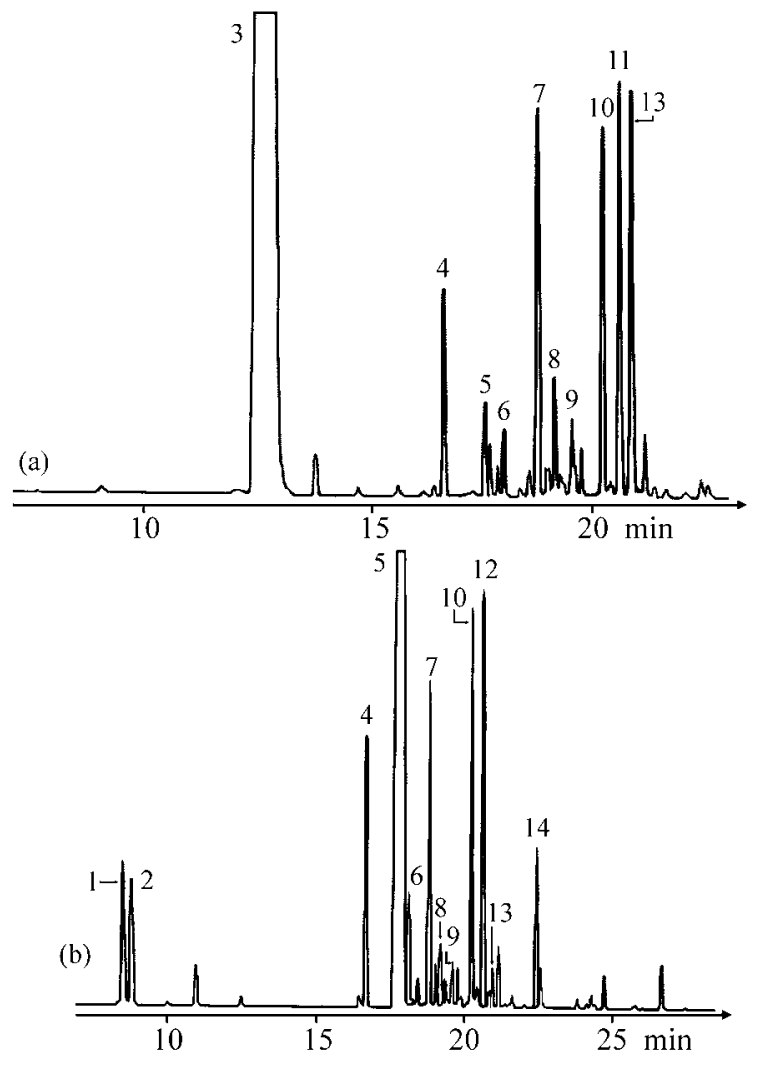

Figure 2. Chromatogram of the essential oil from the flowers of Ocimum selloi Benth.: (a) accession A and (b) accession B. column chromatography on silica gel and the major compound was obtained in a pure form. The IR spectrum of this compound was identical to the corresponding data for estragole reported in the literature ${ }^{4}$. The ${ }^{1} \mathrm{H}-\mathrm{NMR}$ spectrum confirmed the proposed structure.

The structure for some of the minor constituents were proposed by comparison of their mass spectrum with the mass spectrometer data bank (Table 1). All these compounds have already been identified from several other species in this genus ${ }^{5}$. Although the lack of pure references samples makes it difficult to have complete confidence in the proposed identification, this is not a problem for the present investigation, as for the differenciation between two chemotypes only the major oil components are considered $^{6}$.

The essential oil of accession B was also submitted to a column chromatography purification and the major constituent was isolated. The structure for this compound was initially proposed from GC/MS data as methyleugenol (Fig. 3) and was further confirmed by analysis of its IR and ${ }^{1} \mathrm{H}-\mathrm{NMR}$ data.

The characterization of the minor constituents was also carried out by GC/MS as previously mentioned (Table 1).

With pure samples of estragole and methyleugenol available to be used as standards, a quantitative analy sis of these two components in the oil from the leaves and flowers was carried out by gas chromatography,

Table 1. Composition of the essential oil from the leaves and flowers of Ocimum selloi Benth.

\begin{tabular}{|c|c|c|c|c|c|c|c|}
\hline \multirow{3}{*}{$\begin{array}{l}\text { Peak } \\
\mathrm{N}^{\circ} \text {. }\end{array}$} & \multirow{3}{*}{ Component } & \multirow{3}{*}{ M.W. } & \multirow{3}{*}{ R.T./min } & \multicolumn{2}{|c|}{ Acession A } & \multicolumn{2}{|c|}{ Acession B } \\
\hline & & & & Flower & Leaves & Flower & Leaves \\
\hline & & & & \multicolumn{2}{|c|}{ Area $(\%)$} & \multicolumn{2}{|c|}{ Area $(\%)$} \\
\hline 1 & $\mathrm{E}$ or $\mathrm{Z}$ ocimene & 136 & 8.53 & - & - & 2.50 & $\mathrm{t}$ \\
\hline 2 & E or $Z$ ocimene & 136 & 8.82 & - & - & 2.20 & $\mathrm{t}$ \\
\hline 3 & Estragole & 148 & 12.83 & 81.81 & 80.70 & - & - \\
\hline 4 & $?$ & 204 & 16.70 & 1.69 & 1.81 & 4.60 & 3.19 \\
\hline 5 & Methyleugenol & 178 & 17.64 & 0.79 & 1.13 & 63.00 & 63.08 \\
\hline 6 & $?$ & 204 & 18.15 & 0.63 & 0.56 & 2.00 & 1.36 \\
\hline 7 & Trans-caryophyllene & 204 & 18.83 & 3.17 & 4.30 & 5.50 & 6.84 \\
\hline 8 & Bergamotene & 204 & 19.20 & 0.95 & 0.79 & 1.09 & 0.91 \\
\hline 9 & $\alpha$-Humulene & 204 & 19.57 & 0.37 & $\mathrm{t}^{*}$ & 1.20 & $\mathrm{t}$ \\
\hline 10 & Bicyclosesquiphellandrene & 204 & 20.22 & 2.96 & 4.56 & 6.79 & 7.76 \\
\hline 11 & Germacrene B & 204 & 20.62 & 3.38 & 4.56 & - & 11.87 \\
\hline 12 & Bisabolene epoxide & 220 & 20.67 & - & - & 7.11 & - \\
\hline 13 & $\beta$-Bisabolene & 204 & 20.87 & 3.22 & 1.13 & $\mathrm{t}$ & 2.73 \\
\hline 14 & $?$ & 222 & 22.40 & - & - & 2.79 & 1.37 \\
\hline
\end{tabular}

? sesquiterpene not identified; * $\mathrm{t}$, trace amount. 
<smiles>C=CCc1ccc(OC)cc1</smiles>

Estragole

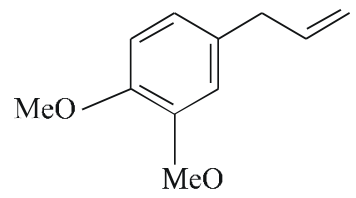

Methyleugenol
Figure 3. Major constituents from the essential oil of Ocimum selloi Benth.

using the calibration curve method ${ }^{7}$. The percentage of estragole in the oil from the leaves and flowers of acces sion A was $94.95 \pm 1.02 \%$ (average \pm standard deviation) and $92.54 \pm 0.78 \%$ respectively. For accession B the percentage of methyleugenol in the oil from the leaves and flowers was $65.49 \pm 3.43 \%$ and $66.18 \pm 1.97 \%$ respectively.

For each accession the chemical composition of the oil from the leaves and flowers were very similar. For accession $\mathrm{B}$, the major difference observed was the presence of a reason able amount of compounds 2 and 9 in the flowers, while in the leaves these compounds were present in trace amounts. Also compound $\mathbf{1 2}$ was not present in the leaves and was the second major constituent in the oil from the flowers. On the other hand compound $\mathbf{1 1}$ was the second major constituent in the leaves and was not present in the flowers.

For accession A the chemical composition of the oil from the leaves and flowers were very similar in qualitative terms (Table 1).

Between the two accessions, the major difference in the oil chemical composition was the presence of estragole as the major constituent in the leaves and flowers of accession A and its absence in accession B. On the other hand, the major compound found in the oil from the leaves and flowers of accession B was methyleugenol. This compound was found in very small amount in the oil of plants from accession A.

The chemical composition of the essential oil for different Ocimum species has been shown to vary greatly. For example, camphor amounts to $70 \%$ of the essential oil of $O$. kilimadjaricum $^{8}$ and $65 \%$ in the case of $O$. canun $^{5}$. The chemical composition of volatile oil from $O$. basilicum cultivated in different parts of the world has been shown to vary enormously ${ }^{5,9}$.

Ribeiro et al. ${ }^{10}$ has shown the existence of two chemotypes of $O$. nudicaule Benth. The one classified as the anisifolia variety has estragole as the major constituent of its essential oil, the other that has no estragole was classified as the nudicaule variety.

Also the specie Ocimum basilicum known as Sweet basil or French basil has two populary recognized races. One is rich in eugenol and the other is rich in estragole ${ }^{11}$. Thus, the difference in chemical composition found for the two accessions studied is not unique.

Considering that the plants investigated in this work were cultivated under the same conditions, the morphological and chemical differences observed could not be due to ecological factors, but should be a consequence of genetical difference between the two groups of plants ${ }^{10}$. These results suggest that the two accessions studied should constitute two taxonomic varieties of Ocimum selloi. A genetic investigation of these two accessions is underway at the moment in order to corroborate, or not, this hypothesis.

\section{Acknowledgments}

We thank the "Conselho Nacional de Desenvolvimento Científico e Tecnológico" (CNPq) and the "Cordenação de Aperfeiçoamento de Pessoal de Nível Superior" (CAPES) for research (VWDC and LCAB) and graduate (ERM) fellowships.

\section{References}

1. Sobti, S.N.; Pushpangandan, P. In Cultivation and Utilization of Aromatic Plants; Atal, C.K.; Kapur, B.M., Ed.; Regional Research Lab; Jammu-Tawi India,1982, v 03, p 457-472.

2. Guenther, E. In The Essential Oils; R. Krieger; New York, 1972. v 1.

3. Vanderlinde, F.A. et al. In XII Simpósio de Plantas Medicinais do Brasil; UFCE; Fortaleza, 1994, p 156.

4. Pouchert, C.J. In The Aldrich Chemical of Infrared Spectra; Aldrich Chemical; Milwaukee, 1981.

5. Rizk, A.M.; Al-Nowaihi, A.S. In The Phytochemistry of the Horticultural Plants of Qatar; Alden Press; Oxford-UK, 1989.

6. Franz, C. In Volatile Oil Crops: Their Biology, Biochemistry; Hay, R.K.M; Waterman, P.G., Ed.; Longmam Scientific \& Technical; Bath, 1993, p 63.

7. Collins, C.H.; Braga, G.L.; Bonato, P.S. In Introdução a Métodos Cromatográficos; UNICAMP; Campinas, 1990.

8. Nayak, U.G.; Guha, P.C. Indian Chem. Soc. 1952, 29, 112.

9. Khorana, M.L.; Vangikan, M.B. Indian J. Pharm. 1983, 12, 132.

10. Ribeiro, R.C.L.F.; Giulietti, A.M.; Barradas, M.M.; Salatino, A. Anais da Academia Brasileira de Ciências 1972, 44, p 65-71.

11. Gupta, R. In G-15 Gene Banks for Medicinal and Aromatic Plants Newsletter No.5; Cenargen/EMBRAPA; Brasilia, 1994. 